\title{
Allergic Reaction
}

National Cancer Institute

\section{Source}

National Cancer Institute. Allergic Reaction. NCI Thesaurus. Code C114476.

An immune response that occurs following re-exposure to an innocuous antigen, and that requires the presence of existing antibodies ag ainst that antigen. This response involves the binding of IgE to mast cells, and may worsen with repeated exposures. 